\title{
Editorial
}

\section{A New Era in Stereotactic Brain Biopsy: Frameless Navigation-Based System}

Taweesomboonyat et al. presented their experience in frameless stereotactic brain biopsy in their article: "Diagnostic yield and complication of frameless stereotactic brain biopsy." "[1]

Surgery is the mainstay of treatment for brain tumors to make pathological diagnosis, to relieve mass effect, and to improve prognosis. If surgery is not feasible (deep-seated lesion or lesion located in the eloquent brain area, small, and/or multiple lesions), stereotactic brain biopsy is a viable option for histopathological assessment of the tumor to make further treatment plan.

Frame-based stereotactic brain biopsy systems have been used for a long time. Stereotactic brain biopsies have a mortality rate of $3.5 \%$, over than expected even though they provide diagnosis with precision..$^{[2,3]}$ With technical and technological advancement, morbidity and mortality rates of stereotactic brain biopsies have steadily decreased from the $1980 \mathrm{~s}$ to $2000 \mathrm{~s} .{ }^{[3]}$ Through advancement in navigation technology, frameless stereotactic brain biopsy settings have been installed compatible with both magnetic resonance imaging (MRI) and computed tomography (CT). ${ }^{[2]}$ Pointer-based referencing that uses either fiducial markers or anatomical landmarks is employed in frameless stereotaxy. ${ }^{[4]}$

Frameless stereotactic brain biopsy has comparable accuracy and complication rates to frame-based systems. Frameless stereotaxy is convenient both for the patient (more comfortable setting) and surgeon (time- and cost-saving). ${ }^{[2,5-7]}$ It is even better to use a frameless stereotaxy system free of head fixation equipment (namely, Mayfield head holder), which is intolerable for awake patients, limits biopsy planning, and leads to postoperative complications (bone fracture, cerebrospinal fluid leakage, and epidural hematoma). ${ }^{[8]}$

As a limitation of frameless stereotaxy, its accuracy is less for posterior fossa lesions. ${ }^{[6]}$ The error of frameless stereotaxy in phantom subjects is $1.3-1.7 \mathrm{~mm}$ with MRI, even lesser with $\mathrm{CT}(1.1 \mathrm{~mm} \pm 0.5 \mathrm{~mm}) \cdot{ }^{[5]} \mathrm{CT}$ is also more beneficial than MRI in financial aspects for rural sites of the world.

As understanding of the main principles of frameless stereotactic brain biopsy is disseminated throughout the world, it would once replace frame-based systems in the near future.

\section{Financial support and sponsorship}

Nil.

\section{Conflicts of interest}

There are no conflicts of interest.

Murat Şakir Ekşi

Department of Neurosurgery, School of Medicine, Acibadem Mehmet Ali Aydinlar University, Istanbul, Turkey

Address for correspondence: Dr. Murat Şakir Ekşi, Göztepe Mah, Mesire Sok, Tütüncü Mehmet Efendi Cad, Tepekule Apart, No: 3/34, Kadıköy, Istanbul, Turkey. E-mail: muratsakireksi@gmail.com

\section{REFERENCES}

1. Taweesomboonyat C, Tunthanathip T, Sae-Heng S, Oearsakul T. Diagnostic yield and complication of frameless stereotactic brain biopsy. J Neurosci Rural Pract 2018;10:78-84.

2. Paleologos TS, Dorward NL, Wadley JP, Thomas DG. Clinical validation of true frameless stereotactic biopsy: Analysis of the first 125 consecutive cases. Neurosurgery 2001;49:830-5.

3. Johnson DR, O’Neill BP, Decker PA, Kosel ML, Lanzino G, Hammack JE. Mortality and discharge to home after closed brain biopsy: Analysis of 3523 cases from the state of California, 2003-2009. World Neurosurg 2013;79:110-5.

4. Amin DV, Lozanne K, Parry PV, Engh JA, Seelman K, Mintz A, et al. Image-guided frameless stereotactic needle biopsy in awake patients without the use of rigid head fixation. J Neurosurg 2011;114:1414-20.

5. Dorward NL, Alberti O, Palmer JD, Kitchen ND, Thomas DG. Accuracy of true frameless stereotaxy: In vivo measurement and laboratory phantom studies. Technical note. J Neurosurg 1999;90:160-8.

6. Barnett GH, Miller DW, Weisenberger J. Frameless stereotaxy with scalp-applied fiducial markers for brain biopsy procedures: Experience in 218 cases. J Neurosurg 1999;91:569-76.

7. Germano IM, Queenan JV. Clinical experience with intracranial brain needle biopsy using frameless surgical navigation. Comput Aided Surg 1998;3:33-9.

8. Reichter RE, Park HM, Hall D. Skull defects due to mayfield head stabilizer. Clin Nucl Med 1983;8:553.

This is an open access journal, and articles are distributed under the terms of the Creative Commons Attribution-NonCommercial-ShareAlike 4.0 License, which allows others to remix, tweak, and build upon the work non-commercially, as long as appropriate credit is given and the new creations are licensed under the identical terms.

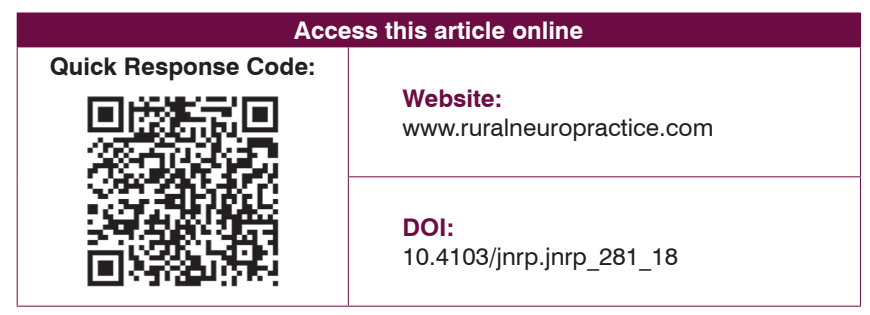

How to cite this article: Ekşi MŞ. A new era in stereotactic brain biopsy: Frameless navigation-based system. J Neurosci Rural Pract 2019;10:3. 